\title{
Natural variation and artificial selection of photoperiodic flowering genes and their applications in crop adaptation
}

\author{
Xiaoya Lin ${ }^{1}$, Chao Fang ${ }^{1}$, Baohui Liu ${ }^{1}$, Fanjiang Kong ${ }^{1 \bowtie}$ \\ 1 Innovative Center of Molecular Genetics and Evolution, School of Life Sciences, Guangzhou University, Guangzhou, \\ China
}

Received: 12 January 2021 / Accepted: 8 March 2021 / Published online: 2 June 2021

\begin{abstract}
Flowering links vegetative growth and reproductive growth and involves the coordination of local environmental cues and plant genetic information. Appropriate timing of floral initiation and maturation in both wild and cultivated plants is important to their fitness and productivity in a given growth environment. The domestication of plants into crops, and later crop expansion and improvement, has often involved selection for early flowering. In this review, we analyze the basic rules for photoperiodic adaptation in several economically important and/or well-researched crop species. The ancestors of rice (Oryza sativa), maize (Zea mays), soybean (Glycine max), and tomato (Solanum lycopersicum) are short-day plants whose photosensitivity was reduced or lost during domestication and expansion to high-latitude areas. Wheat (Triticum aestivum) and barley (Hordeum vulgare) are long-day crops whose photosensitivity is influenced by both latitude and vernalization type. Here, we summarize recent studies about where these crops were domesticated, how they adapted to photoperiodic conditions as their growing area expanded from domestication locations to modern cultivating regions, and how allelic variants of photoperiodic flowering genes were selected during this process. A deeper understanding of photoperiodic flowering in each crop will enable better molecular design and breeding of high-yielding cultivars suited to particular local environments.
\end{abstract}

Keywords Adaptation, Photoperiodic flowering, Crops, Artificial selection

\section{INTRODUCTION}

The history of agriculture is the process of artificial selection of numerous plants and animals. Humans began to settle down and establish agricultural societies in which they artificially domesticated wild animals and cultivated plants as crops. Natural mutations at different gene loci provided the driving force for intensive

Xiaoya Lin and Chao Fang contributed equally to this paper.

Supplementary Information The online version contains supplementary material available at https://doi.org/10.1007/ s42994-021-00039-0.

$\bowtie$ Correspondence: kongfj@gzhu.edu.cn (F. Kong) artificial selection, which can be divided into two stages: domestication and improvement. The domestication stage is characterized by continuous artificial selection by farmers of individual plants with excellent agronomic traits and further expansion of planting. In this process, landraces are developed. During the improvement stage, breeders cross varieties with different desired agronomic traits to obtain cultivars that combine multiple advantages (Meyer and Purugganan 2013). As human societies developed, the spread of different crops has brought a more stable food supply, so that huntergatherers could settle down in villages with larger populations and ultimately form more complex societies and cultures. However, plants respond strongly to changes in photoperiod and do not adapt easily to new 
environments and different latitudinal areas, which has sometimes hindered human agricultural activities.

Flowering plants sense day/night length as a seasonal cue to flower. Plants can be categorized into three groups according to their photoperiodic flowering response. Long-day (LD) plants flower when exposed to light periods longer than a certain critical time; shortday (SD) plants require a long period of darkness, and thus a short day, before they flower; and day-neutral plants flower regardless of the day length (Garner and Allard 1920). This photoperiodic habit of flowering is usually determined by where the plant originates. Plants that originated near the equator, where day length is relatively constant throughout the year, usually do not respond to changes in day length. Plants that originated at low or high latitudes usually flower in response to short or long days, respectively (Brambilla et al. 2017). In addition, some plants require vernalization (a long period of cold) to relieve the inhibition of flowering before they respond to photoperiod signals.

Most plants have an obvious photoperiodic flowering response, and the time of flowering determines the adaptability and influences the final yield of crops. Therefore, photoperiodic flowering is a major factor in the process of artificial selection. In this regard, one of the goals of farmers and breeders is to acclimate crops to local photoperiod conditions, such that they flower and mature in an appropriate season or period, and ultimately meet human needs for crop yield. In this process, some alleles of important photoperiod response genes have been unconsciously selected by humans. Artificial selection thus produces crops that are superior to their ancestors in terms of agronomic traits may better adapt to new areas than their progenitors. Each crop has a unique history of domestication and improvement. In this review, we summarize how six crops, two LD crops and four SD crops, changed to adapt to new photoperiodic conditions over their evolutionary histories.

\section{WHEAT AND BARLEY: VERNALIZATION AFFECTS REGIONAL PHOTOPERIODIC FLOWERING ACCLIMATION}

Wheat and barley are typical LD crops that originated in western Asia, in and near the so-called Fertile Crescent, an area characterized by the alternation of cold and warm seasons (Jones et al. 2008; Haas et al. 2019). Barley was domesticated from its wild ancestor Hordeum spontaneum. The emergence of wheat (Triticum aestivum) involved two stages: Triticum urartu (with an AA genome) and Aegilops peltoides (BB genome) hybridized to form emmer wheat, Triticum turgidum (AABB genome), which then hybridized with Aegilops tauschii (DD genome) to produce the hexaploid wheat Triticum aestivum (AABBDD genome) (Kilian et al. 2010). Wheat and barley can each be characterized into two categories according to their requirement for vernalization: the winter types require a period of cold before they become competent to flower, whereas the spring types do not. Two genes are associated with vernalization in cereals-VRN1/FUL1/WAP1 and VRN2-both of which are critical for adaptation to autumn sowing. VERNALIZATION1 (VRN1) encodes an AP1-like MADS-box transcription factor, VERNALIZATION1, a homolog of Arabidopsis AP1, and its transcription is induced by vernalization (Yan et al. 2003). The VRN2 locus contains two similar genes, ZCCT1 and ZCCT2 (Yan et al. 2004). VRN1 binds directly to the promoter regions of VRN2 (both ZCCT1 and ZCCT2) and VRN3 (also known as FT1) to regulate their transcription (Deng et al. 2015). VRN2 inhibits FT1 expression, and after prolonged cold exposure, plants can flower under LD conditions.

Although vernalization is not a photoperiodic response, it enables winter sowing in addition to regular spring sowing. The differences in sowing and growing times lead to distinct preferences for photoperiod sensitivity when breeding winter or spring wheat and barley. For example, the spring types of grain crops are sown in spring and harvested in autumn. Their growing season occurs in summer, when crops respond to LD conditions at high latitudes and to SD conditions at low latitudes. At high latitudes, to prevent loss of yield caused by early heading, the response to LD-induced heading must be weaker. To avoid heat and possible summer drought during the seed setting stage in tropical regions, late heading should be discouraged and photosensitivity reduced in cereals through artificial selection. The winter types are sown in autumn and harvested the next summer, so the whole growing season consists of SD conditions. Therefore, reduced sensitivity to SD conditions is required for heading. However, at high latitudes, the summer is mild and conducive to setting, so the heading date can be relatively late compared to that of winter cereals adapted to relatively low latitudes (Table S1).

The major locus conferring photoperiodic sensitivity in cereals is PHOTOPERIOD1 (Ppd1), which belongs to the pseudo-response regulator (PRR) gene family. The corresponding gene in barley is known as Ppd-H1 because barley contains the $\mathrm{HH}$ genome (Turner et al. 2005). The prevalence of the Ppd-H1a allele (the insensitive allele, Table S1), which originated from wild barley, increased as barley adapted to the high latitudes 
of Europe. This indicates that as barley was acclimating to high latitudes with LD conditions, people chose lateheading cultivars to ensure sufficient yield (Jones et al. 2008). The corresponding genes in wheat are $P p d-A 1$ (in the AA genome), $P p d-B 1$ (in the BB genome), and $P p d-$ $D 1$ (in the DD genome); Ppd-D1 contributes the most to the heading date of winter wheat. The two alleles of this gene, $P p d-D 1 a$ (which is missing 2,089 bp in the $5^{\prime}$ upstream region of $P P D-D 1$ ) and $P p d-D 1 b$, can lead to a difference of 10 days in the heading time (Würschum et al. 2018; Seki et al. 2011). Ppd-D1a is favored in winter wheat in the southern parts of both Europe and Japan to accelerate heading and thereby avoid hot summers or local rainy seasons (Würschum et al. 2018; Seki et al. 2011). In Chinese wheat, the frequency of the $P p d-D 1 a$ allele increased from $38.6 \%$ in the landrace to $90.6 \%$ in improved cultivars, indicative of significant selection for this allele during the improvement process (Yang et al. 2009). In the northern United States, spring wheat is grown in advance to increase the duration of vegetative growth, thus increasing yields. With this strategy, the photoperiod-sensitive allele $P p d-D 1 b$ is preferable (Lanning et al. 2012).

The effect of $P p d-B 1$ on wheat photoperiod flowering is mainly reflected in its copy number variation. The copy number of $P p d-B 1$ increases from north to south in European winter wheat cultivars. Higher Ppd-B1 copy number can cause the induction of gene expression resulting in photoperiod insensitivity, enabling a cultivar planted in a southern area to head early and avoid high temperatures and drought (Würschum et al. 2015, 2018; Díaz et al. 2012). Mutations in the Ppd-B1 gene region can also lead to changes in gene function. In Japanese wheat, a 308-bp insertion upstream of Ppd-B1 can cause photoperiod insensitivity and an early flowering phenotype (Nishida et al. 2013b). The effects of $P p d-D 1$ and $P p d-B 1$ on photoperiod flowering are additive: an increase in the copy number of $P p d-B 1$ leading to earlier heading is observed in both the $P p d$ $D 1 b$ and the photoperiod-insensitive Ppd-D1a backgrounds (Würschum et al. 2018).

In winter wheat in Japan, heading date is significantly earlier in the $P p d-B 1 a / P p d-D 1 a$ genotype than the $P p d$ $B 1 b / P p d-D 1 a$ genotype, and winter wheat with $P p d-B 1 a$ is distributed in mid- and low-latitude regions (Seki et al. 2011). In addition, the $P p d-B 1 a / P p d-D 1 b$ genotype is not found in improved cultivars of Japanese wheat, suggesting that the mutations of $P p d-D 1 a$ and $P p d-B 1 a$ are part of a stepwise selection process that finely regulates heading time in regions with different climates (Seki et al. 2011).

There is a similar insensitive mutant for $P p d-A 1$ : a 1,085-bp deletion upstream of Ppd-A1a in Japanese wheat can lead to photoperiod-insensitive phenotypes with early flowering (Nishida et al. 2013b). Among 240 Japanese cultivars, only a few Hokkaido winter wheat cultivars, and no spring wheat cultivars, carry the Ppd$A 1 a$ allele. Cultivars with the Ppd-A1a allele show early heading when grown in the Kanto region, but early heading by only 2.5 days in the Hokkaido region. The mutant allele of this gene does not seem to be widespread, however (Seki et al. 2013). Perhaps the presence of $P p d-A 1 a$ further fine-tunes the photoperiod sensitivity of winter wheat in relatively high-latitude areas.

PhyC and $C O$ are also important for the photoperiod flowering of barley and wheat, but whether they play a significant role in latitude adaptability is not known (Beales et al. 2005; Chen et al. 2014; Nishida et al. 2013a; Shaw et al. 2020; Mulki and von Korff 2016).

\section{SOYBEAN: TWO DIRECTIONS OF EVOLUTION AND ADAPTATION - PROMOTE OR DELAY FLOWERING}

Soybean (Glycine max) was most likely domesticated in central China around the Huang-Huai Valley, a mid-latitude temperate region, from its wild progenitor Glycine soja 5,000 years ago (Sedivy et al. 2017). The subsequent worldwide expansion of soybean to South Korea, Japan, South Asia, and Southeast Asia began 2,000 years ago, and the species reached North America in 1765 and South America in the early twentieth century (Stacey 2008). Adjustment of flowering phenology to photoperiod-based seasonal cues in particular growth environments may have been a driving force for the expansion of cultivation areas toward higher and lower latitudes. To adapt to the northern parts of China, Korea, and Japan, soybean required reduced photoperiod sensitivity and early flowering to allow it to mature before the first frost. However, to better suit lower-latitude areas such as Brazil and Southeast Asia, flowering needed to be delayed to maximize yield.

Natural variations at soybean photoperiodic flowering gene loci contributed to soybean domestication and subsequent diversification. In the process of domestication, mutations in Tof12 (PRR3a) laid the foundation for adaptation to primitive cultivation of soybean and further adaptation towards northern areas ( $\mathrm{Li}$ et al. 2019,2020a; Wang et al. 2020; Lu et al. 2020). The lossof-function allele tof12, which results in early flowering, is enriched in landraces compared to wild soybean, especially in the northeast region of China (Lu et al. 2020). Recently, for the first time, early flowering phenology was molecularly confirmed as a core 
domesticated trait in soybean (Gong 2020). It is easy to imagine early flowering as a trait selected during domestication because modern agriculture favors early and synchronized maturation. However, GsFT2c in $G$. soja is a functional gene, unlike GmFT2c in G. max, and overexpression of GsFT2c in Arabidopsis can induce early flowering (Wu et al. 2017). A variant of GmFT2c with a transposon insertion mutation allele is basically fixed in soybean landraces, indicating that this mutation occurred in the early stages of domestication. Hence, soybean $F T 2 c$ may have been involved in the evolution of the regulation of photoperiodic flowering during soybean domestication (Li et al. 2014; Wu et al. 2017). Although domesticated GmFT2c shows no obvious latitudinal trend in distribution, it causes late flowering in soybean only under SD conditions. Mutation of FT2c might thus be classified as an early step of adaptation to lower latitudes, which does not influence adaptation to higher latitudes.

As plants acclimated to higher latitudes in Asia and North America, various mutations affecting reproductive phenology were selected for and contributed to the expansion of cultivation areas in the process of diversification or improvement. The loss-of-function tof11 (prr $3 b$ ) and $e 2$ ( $g i$ ) alleles contribute to flowering time adaptation in which earlier flowering and maturation is preferred (Wang et al. 2016; Lu et al. 2020; Xu et al. 2013; Watanabe et al. 2011). E3 and E4 are two phytochrome A proteins that predominate under high red/far-red (R/FR) ratio light and low R/FR ratio light, respectively (Cober et al. 1996a, b; Liu et al. 2008; Watanabe et al. 2009). E1 and E1La/b, the legumespecific B3 domain transcriptional factors, inhibit the transcription of florigen, GmFT2a, and GmFT5a (Xia et al. 2012; Xu et al. 2015; Zhu et al. 2019). Different combinations of natural variations at the $E 3, E 4$, and $E 1 /$ E1lb loci, such as e3 e4, e1 e3; e1 e4, e1-as e3; and e1-as $e 1 l b e 3$, reduce soybean photoperiod sensitivity, expanding the cultivation area of soybean toward higher latitudes (Xu et al. 2013; Zhu et al. 2019). The E3, E4, and $E 1$ family may have complicated genetic interactions in which E1 plays the central role in the photoperiodic flowering signaling pathway (Xu et al. 2013; Xia et al. 2012; Zhu et al. 2019). In addition, the soybean SKIP ortholog GmGBP1 positively functions in photoperiod-mediated flowering pathways. The promoter region of GmGBP1 is under selection during soybean migration to higher latitudes (Zhao et al. 2018).

Mutation of the $J$ (ELF3 homologue) locus, on the other hand, provides advantages for soybeans in adapting to lower latitudes and increases yield (Lu et al. 2017). The utilization of the various $j$ alleles has made Brazil the second-largest soybean producer in the world and changed the global soybean trade pattern. Loss of function of $j$ releases the inhibition of $E 1$ transcription, which leads to late flowering. Since $J$ is genetically dependent on $E 1$ (Lu et al. 2017), the dominant $E 1$ allele might be the basis for adaptation to low latitudes (Lin et al. 2020; Miranda et al. 2020). More evidence may be needed to support such a conclusion.

Soybean has 10 FT homologues, of which GmFT2a and GmFT5 $a$ play the major roles in promoting flowering (Kong et al. 2010). Polymorphism association analysis also showed that GmFT2a and GmFT5a induce flowering time in a panel of 127 accessions (Jiang et al. 2019). Haplotypes of GmFT2a and GmFT5a display varying frequency among different soybean maturity groups (a classification based on flowering time according to the latitudinal adaptation), implying that they are involved in the adaptability of soybean to tropical and high-latitude regions, respectively (Zhao et al. 2016; Cai et al. 2020).

\section{RICE: REDUCE AND MAINTAIN PHOTOPERIOD SENSITIVITY IN THE NORTH AND SOUTH, RESPECTIVELY}

Rice is one of the world's most important staple foods. Cultivated rice (Oryza sativa) is domesticated from its progenitor (Oryza rufipogon). There are several subspecies of rice, including japonica and indica, and there has long been debate about their origins and domestication locations. Some genetic studies have shown that the japonica subspecies was first domesticated in the Yangtze River valley (Molina et al. 2011) or the Pearl River Basin (Huang et al. 2012) in China, while archeological evidence suggests that rice was first domesticated in the Yangtze River valley in southern China 10,000-8,000 years ago (Gross and Zhao 2014). Some researchers believe that japonica was domesticated first and then spread north, with one branch spreading south and entering southeast Asia, where it crossed with local wild rice and underwent a second domestication, resulting in a new subspecies, indica (Huang et al. 2012). There is also evidence suggesting that these two subspecies were independently domesticated (Civáň et al. 2015; Wang et al. 2018).

Rice is widely cultivated between latitudes $53^{\circ} \mathrm{N}$ and $40^{\circ} \mathrm{S}$. As rice has adapted to higher latitudes, its sensitivity to photoperiod has been gradually lost to avoid delayed flowering in LD conditions. Among rice varieties grown in extreme northern regions, including northern Europe, northern Japan, northeastern provinces of China, and the far eastern parts of Russia $\left(40^{\circ}-53^{\circ} \mathrm{N}\right)$, all elite cultivars have no or very weak photoperiod 
response (Fujino and Sekiguchi 2005; Wei et al. 2008). Several genes, including $H d 1$, Ghd7, Ghd8, Hd2, DTH2, $H d 6$, and Hd16, play pivotal roles in reducing rice photosensitivity in LD conditions.

Hd1 is a homologue of the Arabidopsis gene CONSTANS (Yano et al. 2000). Hd1 has a dual role in rice photoperiodic flowering: It inhibits flowering under LD conditions but promotes it under SD conditions (Yano et al. 2000; Hayama et al. 2003). The mutant form $h d 1$ is widely selected in high latitudes and is also found in tropical regions (Takahashi et al. 2009; Goretti et al. 2017). A 2-bp deletion in Hd1 appears in many subspecies, which implies that this mutation occurred and was selected for before these subspecies differentiated (Itoh et al. 2018; Fujino et al. 2010). Ghd7/Hd4 is a transcription factor containing a CCT domain but not a B-box zinc finger structure, and it does not have high homology with other CCT proteins of Arabidopsis, rice, wheat, or barley. The distribution of its haplotype in Asia varies significantly with latitude and its corresponding duration of growth. Rice that possesses the loss-of-function allele of $g h d 7$ has reduced photoperiod sensitivity (Xue et al. 2008; Gao et al. 2014). Hd5/Ghd8/ DTH8/LHD1 is a putative HAP3/NF-YB/CBF-A subunit of the CCAAT-box-binding transcription factor, which causes late heading. Rice with a mutant form of ghd8 has a decreased sensitivity to photoperiod (Dai et al. 2012; Fujino et al. 2013; Wei et al. 2010).

The three genes Ghd7, DTH8/Ghd8, and Hd1 combine to synergistically and finely regulate the flowering time of rice, which contributes greatly to rice's adaptability to different latitudes and weather conditions. In the absence of Ghd7 and Ghd8, Hd1 is a heading-promoting factor; when Ghd7 and Ghd8 are present, Hd1 can form a complex with either or both to inhibit the expression of Ehd1, thereby inhibiting the transcription of Heading date $3 a(H d 3 a)$ and Rice flowering locus T1 (RFT1) (Zong et al. 2020). Allelic combinations of these three genes largely determine the photoperiodic response of rice. When all three proteins are present, rice shows strong or very strong photoperiod sensitivity; if any of the three proteins is absent, rice exhibits moderate photoperiod sensitivity; and if two or three are missing, rice has weak photoperiod sensitivity (Zong et al. 2020). In tropical and subtropical regions of China, almost all wild rice accessions and landraces have strong or very strong photoperiod sensitivity and grow quite poorly at other latitudes. In central and southern China, as an adaptation to the double-season cropping system, early-maturing varieties predominate. As a result, indica cultivars (with the genotype hd1 Ghd7 ghd8), which have weak photoperiod sensitivity, are generally cultivated there. In central China, where single cropping is used, the heading time of rice can be relatively delayed to enhance yield. There, japonica cultivars (with the genotype Hd1 Ghd7 Ghd8), which have strong photoperiod sensitivity, are cultivated. In the northernmost part of China, rice types with weak photoperiod sensitivity are generally cultivated, including ecotypes with mutations in all three genes (Zhang et al. 2015; Zong et al. 2020; Xue et al. 2008). However, it has also been suggested that functional Ghd8 is crucial for rice to confer cold tolerance (Wang et al. 2019). As a result, most cultivars at high latitude would carry Ghd8 (Zhang et al. 2015; Li et al. 2015).

Hd2/DTH7/PRR37 (Pseudo-response 37) is a member of the circadian clock, and its mutant form is distributed in both high and low latitudes (Koo et al. 2013). PRR37 is a heading inhibitor under natural LD conditions, while the flowering effect is alternative under natural SD conditions depending on the effects of other genes (Zhang et al. 2019). Cultivars with $h d 2 / p r r 37$ and $h d 4 / g h d 7$ double mutation are distributed in the northernmost regions. These two mutations are correlated with cumulative temperature (Koo et al. 2013; Li et al. 2015).

$\mathrm{Wu}$ et al. (2013) found that Days to heading on chromosome 2 (DTH2) genes, encoding proteins in the CONSTANS-like (COL) family, can induce the expression of $H d 3 a$ and RFT1. Two kinds of functional nucleotide polymorphisms can lead to early flowering and improve the fitness of rice in high latitudes (Wu et al. 2013).

RFT1 and Hd3a are both florigens of rice. RFT1 dominates under LD conditions, while Hd3a plays a role mainly under SD conditions (Komiya et al. 2008; Tsuji et al. 2011). Functional RFT1 is required for rice to adapt to high latitudes. Indica and japonica cultivated north of $33^{\circ} \mathrm{N}$ carry functional RFT1 (Zhao et al. 2015), while wild or cultivated rice strains adapted to low latitudes sometimes carry rft1 mutations (Zhao et al. 2015; Ogiso-Tanaka et al. 2013; Naranjo et al. 2014). This is probably because all the above-mentioned genes in rice are genetically dependent on RFT1 to promote flowering under LD conditions in rice.

Hd6, which encodes a subunit of casein kinase 2 (CK2), has kinase activity and modifies Hd1 under LD conditions (Takahashi et al. 2001; Ogiso et al. 2010). Hd16 encodes a casein kinase I (CKI) that functions to phosphorylate Ghd7. A nonsynonymous substitution in Hd16 results in decreased kinase activity and reduced photoperiodic sensitivity of rice (Hori et al. 2013; Kwon et al. 2014). Hd16 also enhances the function of $\mathrm{Hd} 1$ under both LD and SD conditions (Nemoto et al. 2018). Breeders directionally selected the mutated form of $h d 6$ and hd16 in temperate japonica to acclimate it to northern regions (Nemoto et al. 2018). 
When rice expands to lower latitudes, rice flowering is promoted as the day length becomes shorter. However, in rice, in contrast to soybean, delayed flowering time was not strongly selected for at lower latitudes to increase yield. The mutated form of $h d 1$ was selected to avoid extremely early heading under SD conditions in rice (Kim et al. 2018). Another gene, Ehd1, was also edited to avoid extremely early heading under SD conditions (Wu et al. 2020). Rice has a relatively long flowering time (usually over 70 days, according to https://www.ricedata.cn/variety/index.htm) under SD conditions, so local farmers prefer double or triple cropping in the course of a year, rather than prolonging one growth cycle, as the means to increase yield.

\section{MAIZE: AMBITIOUS TO ADAPT TO HIGHER LATITUDES}

Maize (Zea mays) was domesticated from teosinte (Zea mays ssp. Parviglumis), which originated in the tropical balsas river basin of southwestern Mexico and then spread to high latitudes (Matsuoka et al. 2002). Its range was expanded during pre-Columbian times to include cold temperate regions. Globally, maize is the most widely grown crop (http://faostat.fao.org/); the main producing countries are the United States, China, Brazil, India, and Argentina, with latitudes ranging from $40^{\circ} \mathrm{S}$ to $45^{\circ} \mathrm{N}$ (Buckler et al. 2009).

In the early domestication of maize, the early flowering allele of ZEA CENTRORADIALISB (ZCN8), an FT homologue, was strongly selected (Lazakis et al. 2011). The expression of ZCN8 is regulated by the variant SNP1245 , located in a cis-acting element, which causes early flowering by influencing the binding of ZmMADS1 to the promoter region of ZCN8 (Guo et al. 2018). ZmMADS1 is a transcription factor that affects the flowering time of maize (Alter et al. 2016). After the early flowering allele at SNP-1245 became fixed, the early flowering allele at another variant in the ZCN8 promoter, InDel-2339, was further selected during the spread of maize from tropical to temperate regions; thus, $Z C N 8$ has an important effect on the latitude adaptability of maize (Guo et al. 2018). A series of mutations in other genes contributed to the acclimation of maize to higher latitudes in North America, including ZmCCT9, ZmCCT10, Vgt1, ZmMADS69, and ZmMADS67.

ZmCCT9 and ZmCCT10 are homologues of rice Ghd7 and are the key genes for maize photoperiodic flowering, delaying flowering under LD conditions (Yang et al. 2013; Huang et al. 2018). ZmCCT9/ZmCCT10 negatively regulates the expression of ZCN8 to inhibit maize flowering under LD conditions (Yang et al. 2013; Hung et al. 2012; Huang et al. 2018). The insertion of a CATCA-like transposable element (TE) in the promoter region of $Z m C C T 10$ affects the degree of methylation of the promoter sequence, resulting in a decrease in gene expression and earlier flowering. This insertion, which has been selected during the spread from tropical to temperate regions, improves maize latitudinal adaptability (Yang et al. 2013; Hung et al. 2012). In addition, the insertion of a Harbinger-like TE at $57 \mathrm{~kb}$ upstream of ZmCCT9, which inhibits the expression of ZmCCT9 through cis-acting, results in early flowering (Huang et al. 2018; Guo et al. 2018). The insertion in ZmCCT9 accelerated the spread of maize to high-latitude areas (Huang et al. 2018). The CATCA-like TE of ZmCCT10 and the Harbinger-like TE of ZmCCT9 are not observed in surveyed teosinte accessions, indicating that these insertions occurred after the initial domestication of maize (Huang et al. 2018; Yang et al. 2013). The TE insertion at ZmCCT9 shows low frequency at low latitudes but relatively higher frequency at high latitudes. The two insertions at ZmCCT10 and ZmCCT9 occurred sequentially following domestication and exhibit different distribution patterns at different latitudes (Huang et al. 2018).

Vgt1/ZmRap2.7 is an AP2/ERF transcription factor that inhibits ZCN8 expression under LD conditions. Insertion of a miniature inverted-repeat TE (MITE) in Vgt1 was a major target for selection during the adaptation of maize to cool temperate and high-latitude regions (Salvi et al. 2007; Ducrocq et al. 2008; Romero Navarro et al. 2017).

ZmMADS69/qDTA3-2 is a transcription factor that was cloned by quantitative trait locus (QTL) mapping in offspring of crosses between wild and cultivated species. It inhibits the expression of Vgt1, thereby promoting $Z C N 8$ expression and inducing flowering under both LD and SD conditions. The promoter region of ZmMADS69 was selected such that temperate maize varieties have higher expression than tropical maize varieties. ZmMADS69 was a target of artificial selection and played an important role in the spread of maize from the tropics to temperate zones (Liang et al. 2019).

ZCN8 interacts with the basic leucine zipper transcription factor DLF1 (Delayed flowering 1). Through QTL mapping of recombinant inbred lines of maize and teosinte, a QTL $q L B 7-1$ that affects flowering time was identified. The maize allele flowers early, and DLF1 is the most likely candidate gene for this locus. DLF1 promotes floral transition by directly binding to the promoter regions of ZmMADS4 and ZmMADS67 and activating them in the shoot apex. In the evolutionary process from teosinte to maize, both DLF1 and ZmMADS67 were under selection and underwent 
decreases in nucleotide diversity, whereas ZmMADS4 was not under selection. DLF1 and ZmMADS67 may also play an important role in maize adaptation to higher latitudes (Sun et al. 2020).

Besides the above-mentioned genes, investigation of a nested association mapping population also revealed many QTLs that associate with flowering time and adaption, such as DWARF8, ZmPRR37, ZmPHYC2, and ZmCCA1 (Romero Navarro et al. 2017; Buckler et al. 2009; Li et al. 2016). There is some genetic evidence that they control maize flowering time (Li et al. 2020b; Thornsberry et al. 2001). Allelic geographical distributions may help clarify how these genes changed to adapt to different latitudes in evolutionary history. In contrast to the gradually improving understanding of the adaptation mechanism of maize to North America, little is known about how maize adapted to South America before pre-Colombian times.

\section{TOMATO: FROM SD PLANT TO DAY-NEUTRAL PLANT}

The origin of tomato (Solanum lycopersicum) has long been controversial, but the current consensus is that it was domesticated in the Andean region of South America and Mesoamerica, introduced to Europe by the Spanish in the sixteenth century, and then spread all over the world (Blanca et al. 2012). The most likely ancestral progenitor is Solanum pimpinellifolium (Blanca et al. 2012). Cherry tomato is commonly thought to be the intermediate landrace between wild and elite cultivars of tomato (Bergougnoux 2014).

SP5G (SELF PRUNING 5G) is an FT homolog that inhibits flowering. In $S$. pimpinellifolium, it is highly expressed in LD conditions but barely expressed in SD conditions. Reduction of $S P 5 G$ expression or mutation of $S P 5 G$ in improved cultivars attenuates the inhibitory effect of SP5G on SFT (SINGLE FLOWER TRUSS), a florigen that directly induces flowering in tomato, under LD conditions (Shalit et al. 2009). As a result, the sensitivity to photoperiod decreases in LD conditions (Soyk et al. 2017; Pnueli et al. 1998; Zhang et al. 2018).

FTL1 (Flowering Locus T-Like 1) is also an FT homolog but is a promoter of flowering. The expression of FTL1 is much higher under SD conditions than under LD conditions and shows a stronger oscillation pattern. This gene induces the expression of SFT under SD conditions. In the ftl1 mutant, the transcription of SFT drops sharply under SD conditions, leading to delayed flowering, which weakens the induction of flowering under SD conditions in tomatoes (Song et al. 2020).

Mutant $f t 11$ and $s p 5 g$ genotypes of cherry tomato are distributed near tomato origins, and different allelic combinations are enriched in cherry tomato in the same region, indicating that they were selected independently during domestication (Song et al. 2020). sp5g and ftl1 mutant alleles show a high prevalence in cherry tomato (the landrace). Some wild types carry $s p 5 g$ alleles, but no wild type carries $f t l 1$ alleles, which implies that $s p 5 g$ was selected before $f t 11$ during the tomato domestication process (Song et al. 2020). SP5G inhibits SFT in LD conditions, while FTL1 induces SFT in SD conditions. The selection of $s p 5 g$ weakens LD photoperiod sensitivity, whereas the enrichment of ftl1 abolishes the induction of flowering by SD conditions, thus changing tomato from an SD plant to a day-neutral plant (Song et al. 2020).

As tomato migrated from its origin to other parts of Central America and finally was brought to Europe by the Spanish, its circadian rhythms also changed in response to differences in the photoperiods to which it was exposed. Compared with that of wild tomato, the circadian rhythm of improved cultivars has a delayed phase and a longer period, which allowed cultivated tomato to adapt to higher-latitude areas. Genes responsible for altering the circadian rhythm were mutated and fixed during domestication (Müller et al. 2016, 2018). The loss of a single amino acid in EID1 causes delayed phase, prolonged flowering, and elevated chlorophyll content. The EID1 genome region underwent positive selection during domestication, indicating that humans actively selected phase-delayed mutation to adapt to the longer summer environment (Müller et al. 2016). The LNK2 gene controls the length of the period. The mutated versions of this gene are not observed in the wild ancestor and are seldom observed in samples before tomato was cultivated in Mexico. Ink2 was not fixed until the tomato entered Europe in the sixteenth century during its domestication (Müller et al. 2018). The effects of these two genes in regulating the phase and the periodic circadian clock led to synchronization of the circadian rhythm of the internal and external environment as the tomato migrated northward from the equator.

As a response to photoperiodic flowering, cultivated EID1 delays flowering in both LD and SD conditions; the effect of $\operatorname{lnk} 2$ mutation on flowering is unclear. The functional relationship between the genes EID1, LNK2, FTL1, and SP5G in regulating flowering is still a mystery.

\section{PERSPECTIVE}

The strategies through which LD crops and SD crops have adapted to different latitudes are varied. As SD plants migrate to high latitudes, flowering and maturity 

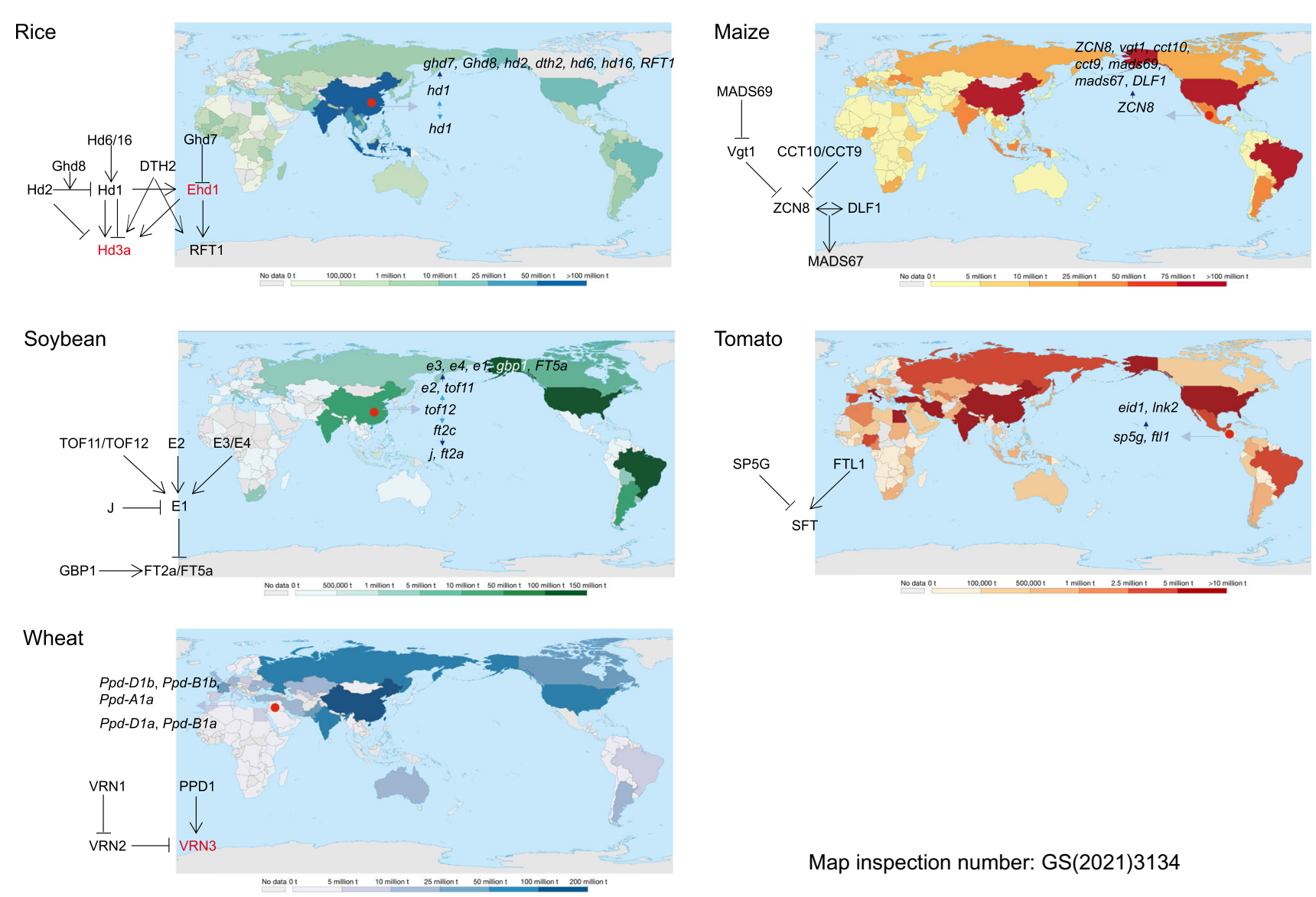

Map inspection number: GS(2021)3134

Fig. 1 The domestication location, modern cultivation region, and selected photoperiodic flowering genes during latitudinal adaptation of each crop. The world crop production maps for year 2018 were downloaded from https://ourworldindata.org/agriculturalproduction\#cereals and adapted. The domestication sites are indicated by red dots. Genes believed to have been selected during the domestication process are followed by the grey arrows. Genes thought to have been selected after domestication or in the improvement process are followed by blue arrows (with light blue arrows indicating earlier selection than dark blue arrows)

are delayed, which makes it difficult to harvest before winter. It is thus necessary to reduce the photoperiod sensitivity to advance flowering and maturity time. As SD plants adapt to lower latitudes, a balance must be struck between advancing flowering and maximizing yield. When temperate-origin LD plants are cultivated at low latitudes, although the flowering time is delayed and the yield is high, the flowering time is often restricted by the local environment or cropping practices. If the summer is particularly hot or dry, the setting stage should be advanced. In addition, land is usually used for multiple crops in a year in tropical and subtropical regions, so delaying flowering time to maximize yield is not the only option; sensitivity to photoperiod should also be reduced. At high latitudes, reduced response to LD induction of flowering is required to keep yield in an appropriate range (Fig. 1).

Each crop regulates photoperiod in a unique way, but there are some common trends. High-quality crop varieties are those that adapt to various growth conditions in different regions, including diverse photoperiod conditions. The abundant natural variations of photoperiodic flowering genes in crops provide alternatives for farmers and breeders, allowing the selection of cultivars to produce sufficient yields in different photoperiod conditions. By comparing how these crops adapted to various regions, we found that the location of domestication, original flowering day, and contingency in adaptation processes all affected the strategy of adaptation. For example, rice and soybean adopted distinct tactics when they expanded their territories to lower latitudes because rice had a relatively longer original flowering time; when maize expanded to highlatitude areas in the north and south, different combinations of genes were selected in the two cases. It is difficult to discern any uniform trends in these processes. Different target genes were often selected as separate species adapted to the same latitude or area and sometimes even as one species adapted to different areas at similar latitudes (Table 1; Fig. 1). However, 
Table 1 Selected photoperiodic flowering genes during latitudinal adaptation of each crop

\begin{tabular}{|c|c|c|c|c|}
\hline Species & Gene names & Encoded proteins & Biological or molecular functions & Corresponding references \\
\hline \multirow[t]{3}{*}{ Wheat } & $P p d-A 1$ & PRR & Circadian clock gene & Seki et al. (2011) \\
\hline & Ppd-B1 & PRR & Circadian clock gene & Díaz et al. (2012) \\
\hline & Ppd-D1 & PRR & Circadian clock gene & Beales et al. (2007) \\
\hline Barley & Ppd-H1 & PRR & Circadian clock gene & Turner et al. (2005) \\
\hline \multirow[t]{11}{*}{ Soybean } & E3 & phyA & Photoreceptor & Watanabe et al. (2009) \\
\hline & $E 4$ & phyA & Photoreceptor & Liu et al. (2008) \\
\hline & E1 & B3-domain protein & Transcriptional factor & Xia et al. (2012) \\
\hline & $E 2$ & GI & & Watanabe et al. (2011) \\
\hline & $G B P 1$ & SKIP & Transcription cofactor & Zhao et al. (2018) \\
\hline & FT5a & & Florigen & Kong et al. (2010) \\
\hline & FT2a & & Florigen & Kong et al. (2010) \\
\hline & Tof11 & PRR & Circadian clock gene & Lu et al. (2020) \\
\hline & Tof12 & PRR & Circadian clock gene & Lu et al. (2020) \\
\hline & $J$ & ELF3 & Circadian clock gene & Lu et al. (2017) \\
\hline & FT2c & FT homolog & Florigen & Wu et al. (2017) \\
\hline \multirow[t]{8}{*}{ Rice } & Ghd7 & CCT domain protein & Transcriptional factor & Xue et al. (2008) \\
\hline & Ghd8 & putative HAP3/NF-YB/CBF-A subunit & A subunit of transcription factor & Dai et al. (2012) \\
\hline & $H d 2$ & PRR37 & Circadian clock gene & Koo et al. (2013) \\
\hline & DTH2 & CONSTANS-like & & Wu et al. (2013) \\
\hline & Hd6 & a subunit of CK2 & Protein kinase & Takahashi et al. (2001) \\
\hline & Hd16 & CKI & Protein kinase & Hori et al. (2013) \\
\hline & RFT1 & FT homolog & Florigen & Komiya et al. (2008) \\
\hline & $H d 1$ & CONSTANS & & Yano et al. (2000) \\
\hline \multirow[t]{7}{*}{ Maize } & ZCN8 & & Florigen & Guo et al. (2018) \\
\hline & Vgt1 & AP2/ERF & Transcriptional factor & Salvi et al. (2007) \\
\hline & CCT10 & CCT domain protein & Transcriptional factor & Hung et al. (2012) \\
\hline & ССТ9 & CCT domain protein & Transcriptional factor & Huang et al. (2018) \\
\hline & MADS69 & MADS-box & Transcriptional factor & Liang et al. (2019) \\
\hline & MADS67 & FUL-like protein & Transcriptional factor & Sun et al. (2020) \\
\hline & $D L F 1$ & Basic leucine zipper protein & Transcriptional factor & Sun et al. (2020) \\
\hline \multirow[t]{4}{*}{ Tomato } & $S P 5 G$ & FT homolog & & Soyk et al. (2017) \\
\hline & FTL1 & FT homolog & & Song et al. (2020) \\
\hline & EID1 & EID1 & F-box protein & Müller et al. (2016) \\
\hline & LNK2 & LNK2 & Circadian clock gene & Müller et al. (2018) \\
\hline
\end{tabular}

certain allelic resources were repeatedly utilized in crop latitudinal adaptation, such as genes in the PRR and FT families.

During domestication and improvement, crops evolve from wild types to landraces and ultimately to improved cultivars. In most crops, these processes are accompanied by some reduction of photoperiod sensitivity. There is an innate contradiction between early maturity and high yield. The best flowering time for a particular crop is the flowering time that makes the best use of the local growth period, thereby maximizing yield. Although day-neutral crops are economical in breeding, and can be cultivated at various latitudes and under most photoperiod conditions, they may not be able to adapt to the natural conditions in a particular area to the greatest extent. Therefore, although a strong photoperiod response is not conducive for adaptation to a wide range of cultivation areas, a certain degree of photoperiod sensitivity should be retained during breeding to make it possible to take advantage of this pivotal physiological factor to increase yields as a crop adapts to different latitudes.

The photoperiod sensitivity of crops is a doubleedged sword. Cultivars with lower photoperiod 
sensitivity have economic benefits and are amenable to cultivation in broad areas but may not produce the greatest yield in every location. As crops become insensitive to photoperiod change through domestication and improvement, the mutant forms of genes selected are usually those upstream of the photoperiodic flowering pathway. Therefore, another breeding method is to choose a cultivar with generally good agronomic traits and then use molecular design to make it completely insensitive to photoperiod. Then, by manipulating the expression of downstream genes such as FT homologues, it is possible to create a series of totally photoperiod-insensitive lines with various flowering times. By investigating the planting conditions in certain areas, we can choose the varieties most suitable for the local photoperiod conditions.

Thanks to research on the origins, distribution, and molecular evolution of several crops, it is becoming clear how these crops immigrated to their modern cultivating region from their domestication centers in view of photoperiodic adaptability. With a richer and more detailed understanding of the photoperiodic flowering pathway in each crop, breeders will be fully equipped to molecularly design cultivars according to local environmental and photoperiodic conditions to maximize yield potential.

Acknowledgements The work was supported by Grants from the National Natural Science Foundation of China to F.K. (32090064) and to X.L. (32001568), and also supported by the Major Program of Guangdong Basic and Applied Research to F.K. (2019B030302006).

Author contributions XL and CF drafted the manuscript. BL revised the manuscript. FK supervised this project and revised the manuscript. All the authors read and approved of its content.

\section{Declarations}

Conflict of interest All the authors have no conflict of interest statement.

Open Access This article is licensed under a Creative Commons Attribution 4.0 International License, which permits use, sharing, adaptation, distribution and reproduction in any medium or format, as long as you give appropriate credit to the original author(s) and the source, provide a link to the Creative Commons licence, and indicate if changes were made. The images or other third party material in this article are included in the article's Creative Commons licence, unless indicated otherwise in a credit line to the material. If material is not included in the article's Creative Commons licence and your intended use is not permitted by statutory regulation or exceeds the permitted use, you will need to obtain permission directly from the copyright holder. To view a copy of this licence, visit http://creativecommons.org/ licenses/by/4.0/.

\section{References}

Alter P, Bircheneder S, Zhou L-Z, Schlüter U, Gahrtz M, Sonnewald $U$, Dresselhaus T (2016) Flowering time regulated genes in Maize include the transcription factor ZmMADS1. Plant Physiol 172:389-404. https://doi.org/10.1104/pp.16.00285

Beales J, Laurie DA, Devos KM (2005) Allelic variation at the linked AP1 and PhyC loci in hexaploid wheat is associated but not perfectly correlated with vernalization response. Theor Appl Genet 110:1099-1107. https://doi.org/10.1007/ s00122-005-1938-3

Beales J, Turner A, Griffiths S, Snape JW, Laurie DA (2007) A Pseudo-response regulator is misexpressed in the photoperiod insensitive Ppd-D1a mutant of wheat (Triticum aestivum L.). Theor Appl Genet 115:721-733. https://doi.org/10. 1007/s00122-007-0603-4

Bergougnoux V (2014) The history of tomato: from domestication to biopharming. Biotechnol Adv 32:170-189. https://doi.org/ 10.1016/j.biotechadv.2013.11.003

Blanca J, Cañizares J, Cordero L, Pascual L, Diez MJ, Nuez F (2012) Variation revealed by SNP genotyping and morphology provides insight into the origin of the Tomato. PLoS ONE 7:e48198. https://doi.org/10.1371/journal.pone.0048198

Brambilla V, Gomez-Ariza J, Cerise M, Fornara F (2017) The importance of being on time: regulatory networks controlling photoperiodic flowering in cereals. Front Plant Sci 8:665. https://doi.org/10.3389/fpls.2017.00665

Buckler ES, Holland JB, Bradbury PJ, Acharya CB, Brown PJ, Browne C, Ersoz E, Flint-Garcia S, Garcia A, Glaubitz JC, Goodman MM, Harjes C, Guill K, Kroon DE, Larsson S, Lepak NK, Li H, Mitchell SE, Pressoir G, Peiffer JA, Rosas MO, Rocheford TR, Romay MC, Romero S, Salvo S, Villeda HS, Sofia da Silva H, Sun Q, Tian F, Upadyayula N, Ware D, Yates H, Yu J, Zhang Z, Kresovich S, McMullen MD (2009) The genetic architecture of maize flowering time. Science 325:714-718. https://doi.org/10.1126/science.1174276

Cai Y, Wang L, Chen L, Wu T, Liu L, Sun S, Wu C, Yao W, Jiang B, Yuan S, Han T, Hou W (2020) Mutagenesis of GmFT2a and GmFT5a mediated by CRISPR/Cas9 contributes for expanding the regional adaptability of soybean. Plant Biotechnol J 18:298-309. https://doi.org/10.1111/pbi.13199

Chen A, Li C, Hu W, Lau MY, Lin H, Rockwell NC, Martin SS, Jernstedt JA, Lagarias JC, Dubcovsky J (2014) PHYTOCHROME $\mathrm{C}$ plays a major role in the acceleration of wheat flowering under long-day photoperiod. Proc Natl Acad Sci USA 111:10037-10044. https://doi.org/10.1073/pnas. 1409795111

Civáň P, Craig H, Cox CJ, Brown TA (2015) Three geographically separate domestications of Asian rice. Nat Plants. https://doi. org/10.1038/nplants.2015.164

Cober ER, Tanner JW, Voldeng HD (1996a) Genetic control of photoperiod response in early-maturing, near-isogenic soybean lines. Crop Sci 36:601. https://doi.org/10.2135/ cropsci1996.0011183X003600030013x

Cober ER, Tanner JW, Voldeng HD (1996b) Soybean photoperiodsensitivity loci respond differentially to light quality. Crop Sci 36:606. https://doi.org/10.2135/cropsci1996. 0011183X003600030014x

Dai X, Ding Y, Tan L, Fu Y, Liu F, Zhu Z, Sun X, Sun X, Gu P, Cai H, Sun C (2012) LHD1, an allele of DTH8/Ghd8, controls late heading date in common wild rice (Oryza rufipogon). J Integr Plant Biol 54:790-799. https://doi.org/10.1111/j.17447909.2012.01166.x

Deng W, Casao MC, Wang P, Sato K, Hayes PM, Finnegan EJ, Trevaskis B (2015) Direct links between the vernalization 
response and other key traits of cereal crops. Nat Commun. https://doi.org/10.1038/ncomms6882

Díaz A, Zikhali M, Turner AS, Isaac P, Laurie DA (2012) Copy number variation affecting the Photoperiod-B1 and Vernalization-A1 genes is associated with altered flowering time in wheat (Triticum aestivum). PLoS ONE 7:e33234. https://doi. org/10.1371/journal.pone.0033234

Ducrocq S, Madur D, Veyrieras J-B, Camus-Kulandaivelu L, KloiberMaitz M, Presterl T, Ouzunova M, Manicacci D, Charcosset A (2008) Key impact of Vgt1 on flowering time adaptation in maize: evidence from association mapping and ecogeographical information. Genetics 178:2433-2437. https://doi.org/ 10.1534/genetics.107.084830

Fujino K, Sekiguchi H (2005) Mapping of QTLs conferring extremely early heading in rice (Oryza sativa L.). Theor Appl Genet 111:393-398. https://doi.org/10.1007/s00122-0052035-3

Fujino K, Wu J, Sekiguchi H, Ito T, Izawa T, Matsumoto T (2010) Multiple introgression events surrounding the Hd1 flowering-time gene in cultivated rice, Oryza sativa L. Mol Genet Genomics 284:137-146. https://doi.org/10.1007/s00438010-0555-2

Fujino K, Yamanouchi U, Yano M (2013) Roles of the Hd5 gene controlling heading date for adaptation to the northern limits of rice cultivation. Theor Appl Genet 126:611-618. https:// doi.org/10.1007/s00122-012-2005-5

Gao H, Jin M, Zheng X-M, Chen J, Yuan D, Xin Y, Wang M, Huang D, Zhang Z, Zhou K, Sheng P, Ma J, Ma W, Deng H, Jiang L, Liu S, Wang H, Wu C, Yuan L, Wan J (2014) Days to heading 7, a major quantitative locus determining photoperiod sensitivity and regional adaptation in rice. Proc Natl Acad Sci USA 111:16337-16342. 1418204111

Garner WW, Allard HA (1920) Effect of the relative length of day and night and other factors of the environment on growth and reproduction in plants. Mon Weather Rev 48:415. https://doi.org/10.1175/1520-0493(1920)48\%3c415b: EOTRLO\%3e2.0.CO;2

Gong Z (2020) Flowering phenology as a core domestication trait in soybean. J Integr Plant Biol 62:546-549. https://doi.org/ 10.1111/jipb.12934

Goretti D, Martignago D, Landini M, Brambilla V, Gómez-Ariza J, Gnesutta N, Galbiati F, Collani S, Takagi H, Terauchi R, Mantovani R, Fornara F (2017) Transcriptional and posttranscriptional mechanisms limit heading date 1 (Hd1) function to adapt rice to high latitudes. PLoS Genet 13:e1006530. https://doi.org/10.1371/journal.pgen. 1006530

Gross BL, Zhao Z (2014) Archaeological and genetic insights into the origins of domesticated rice. Proc Natl Acad Sci USA 111:6190-6197. https://doi.org/10.1073/pnas.1308942110

Guo L, Wang X, Zhao M, Huang C, Li C, Li D, Yang CJ, York AM, Xue W, Xu G, Liang Y, Chen Q Doebley JF, Tian F (2018) Stepwise cis-regulatory changes in ZCN8 contribute to maize flowering-time adaptation. Curr Biol 28:3005-3015.e4. https://doi. org/10.1016/j.cub.2018.07.029

Haas M, Schreiber M, Mascher M (2019) Domestication and crop evolution of wheat and barley: genes, genomics, and future directions. J Integr Plant Biol 61:204-225. https://doi.org/ 10.1111/jipb.12737

Hayama R, Yokoi S, Tamaki S, Yano M, Shimamoto K (2003) Adaptation of photoperiodic control pathways produces short-day flowering in rice. Nature 422:719-722. https:// doi.org/10.1038/nature01549

Hori K, Ogiso-Tanaka E, Matsubara K, Yamanouchi U, Ebana K, Yano M (2013) Hd16, a gene for casein kinase I, is involved in the control of rice flowering time by modulating the daylength response. Plant J 76:36-46. https://doi.org/10.1111/ tpj.12268

Huang X, Kurata N, Wei X, Wang Z-X, Wang A, Zhao Q, Zhao Y, Liu K, Lu H, Li W, Guo Y, Lu Y, Zhou C, Fan D, Weng Q, Zhu C, Huang T, Zhang L, Wang Y, Feng L, Furuumi H, Kubo T, Miyabayashi T, Yuan X, Xu Q Dong G, Zhan Q Li C, Fujiyama A, Toyoda A, Lu T, Feng Q, Qian Q Li J, Han B (2012) A map of rice genome variation reveals the origin of cultivated rice. Nature 490:497-501. https://doi.org/10.1038/nature11532

Huang C, Sun H, Xu D, Chen Q, Liang Y, Wang X, Xu G, Tian J, Wang C, Li D, Wu L, Yang X, Jin W, Doebley JF, Tian F (2018) ZmCCT9 enhances maize adaptation to higher latitudes. Proc Natl Acad Sci USA 115:E334-E341. https://doi.org/10.1073/ pnas.1718058115

Hung H-Y, Shannon LM, Tian F, Bradbury PJ, Chen C, Flint-Garcia SA, McMullen MD, Ware D, Buckler ES, Doebley JF, Holland JB (2012) ZmCCT and the genetic basis of day-length adaptation underlying the postdomestication spread of maize. Proc Natl Acad Sci USA 109:E1913-E1921. https://doi.org/10.1073/ pnas.1203189109

Itoh H, Wada KC, Sakai H, Shibasaki K, Fukuoka S, Wu J, Yonemaru J, Yano M, Izawa T (2018) Genomic adaptation of floweringtime genes during the expansion of rice cultivation area. Plant J 94:895-909. https://doi.org/10.1111/tpj.13906

Jiang B, Zhang S, Song W, Khan MAA, Sun S, Zhang C, Wu T, Wu C, Han $T$ (2019) Natural variations of FT family genes in soybean varieties covering a wide range of maturity groups. BMC Genomics 20:230. https://doi.org/10.1186/s12864019-5577-5

Jones H, Leigh FJ, Mackay I, Bower MA, Smith LMJ, Charles MP, Jones G, Jones MK, Brown TA, Powell W (2008) Populationbased resequencing reveals that the flowering time adaptation of cultivated barley originated east of the fertile crescent. Mol Biol Evol 25:2211-2219. https://doi.org/10.1093/mol bev/msn 167

Kilian B, Martin W, Salamini F (2010) Genetic diversity, evolution and domestication of wheat and barley in the fertile crescent. In: Glaubrecht M. (eds) Evolution in action, pp 137-166. Doi:https://doi.org/10.1007/978-3-642-12425-9_8

Kim S-R, Torollo G, Yoon M-R, Kwak J, Lee C-K, Prahalada GD, Choi I-R, Yeo U-S, Jeong O-Y, Jena KK, Lee J-S (2018) Loss-offunction alleles of heading date 1 (Hd1) are associated with adaptation of temperate japonica rice plants to the tropical region. Front Plant Sci 9:1827. https://doi.org/10.3389/fpls. 2018.01827

Komiya R, Yokoi S, Shimamoto K (2008) A gene network for longday flowering activates RFT1 encoding a mobile flowering signal in rice. Development 136:3443-3450. https://doi.org/ 10.1242/dev.040170

Kong F, Liu B, Xia Z, Sato S, Kim BM, Watanabe S, Yamada T, Tabata S, Kanazawa A, Harada K, Abe J (2010) Two coordinately regulated homologs of Flowering Locus $\mathrm{T}$ are involved in the control of photoperiodic flowering in soybean. Plant Physiol 154:1220-1231. https://doi.org/10.1104/pp.110.160796

Koo B-H, Yoo S-C, Park J-W, Kwon C-T, Lee B-D, An G, Zhang Z, Li J, Li Z, Paek N-C (2013) Natural variation in OsPRR37 regulates heading date and contributes to Rice cultivation at a wide range of latitudes. Mol Plant 6:1877-1888. https://doi.org/ $10.1093 / \mathrm{mp} / \mathrm{sst} 088$

Kwon C-T, Yoo S-C, Koo B-H, Cho S-H, Park J-W, Zhang Z, Li J, Li Z, Paek N-C (2014) Natural variation in Early flowering1 contributes to early flowering in japonica rice under long days. Plant Cell Environ 37:101-112. https://doi.org/10. $1111 /$ pce. 12134 
Lanning SP, Hucl P, Pumphrey M, Carter AH, Lamb PF, Carlson GR, Wichman DM, Kephart KD, Spaner D, Martin JM, Talbert LE (2012) Agronomic performance of spring Wheat as related to planting date and photoperiod response. Crop Sci 52:1633-1639. https://doi.org/10.2135/cropsci2012.01. 0052

Lazakis CM, Coneva V, Colasanti J (2011) ZCN8 encodes a potential orthologue of Arabidopsis FT florigen that integrates both endogenous and photoperiod flowering signals in maize. J Exp Bot 62:4833-4842. https://doi.org/10.1093/jxb/ err129

Li Y, Zhou G, Ma J, Jiang W, Jin L, Zhang Z, Guo Y, Zhang J, Sui Y, Zheng L, Zhang S, Zuo Q Shi X, Li Y, Zhang W, Hu Y, Kong G, Hong H, Tan B, Song J, Liu Z, Wang Y, Ruan H, Yeung CKL, Liu J, Wang H, Zhang L, Guan R, Wang K, Li W, Chen S, Chang R, Jiang Z, Jackson SA, Li R, Qiu L (2014) De novo assembly of soybean wild relatives for pan-genome analysis of diversity and agronomic traits. Nat Biotech 32:1045-1052. https://doi. $\operatorname{org} / 10.1038 /$ nbt.2979

Li X, Liu H, Wang M, Liu H, Tian X, Zhou W, Lü T, Wang Z, Chu C, Fang J, Bu Q (2015) Combinations of $\mathrm{Hd} 2$ and $\mathrm{Hd} 4$ genes determine rice adaptability to Heilongjiang province, northern limit of China. J Integr Plant Biol 57:698-707. https://doi. org/10.1111/jipb.12326

Li Y-X, Li C, Bradbury PJ, Liu X, Lu F, Romay CM, Glaubitz JC, Wu X, Peng B, Shi Y, Song Y, Zhang D, Buckler ES, Zhang Z, Li Y, Wang $\mathrm{T}$ (2016) Identification of genetic variants associated with maize flowering time using an extremely large multi-genetic background population. Plant J 86:391-402. https://doi.org/ 10.1111/tpj.13174

Li M-W, Liu W, Lam H-M, Gendron JM (2019) Characterization of two growth period QTLs reveals modification of PRR3 genes during soybean domestication. Plant Cell Physiol 60:407-420. https://doi.org/10.1093/pcp/pcy215

Li C, Li Y, Li Y, Lu H, Hong H, Yu T, Li H, Zhao T, Zhou X, Liu J, Zhou X, Jackson SA, Liu B, Qiu L (2020a) A domesticationassociated gene GmPRR3b regulates circadian clock and flowering time in soybean. Mol Plant 13:745-759. https:// doi.org/10.1016/j.molp.2020.01.014

Li Q, Wu G, Zhao Y, Wang B, Zhao B, Kong D, Wei H, Chen C, Wang H (2020b) CRISPR/Cas9-mediated knockout and overexpression studies reveal a role of maize phytochrome $\mathrm{C}$ in regulating flowering time and plant height. Plant Biotechnol J. https://doi.org/10.1111/pbi.13429

Liang Y, Liu Q, Wang X, Huang C, Xu G, Hey S, Lin H, Li C, Xu D, Wu L, Wang C, Wu W, Xia J, Han X, Lu S, Lai J, Song W, Schnable PS, Tian F (2019) ZmMADS69 functions as a flowering activator through the ZmRap2.7-ZCN8 regulatory module and contributes to maize flowering time adaptation. New Phytol 221:2335-2347. https://doi.org/10.1111/nph.15512

Lin X, Liu B, Weller JL, Abe J, Kong F (2020) Molecular mechanisms for the photoperiodic regulation of flowering in soybean. J Integr Plant Biol. https://doi.org/10.1111/jipb. 13021

Liu B, Kanazawa A, Matsumura H, Takahashi R, Harada K, Abe J (2008) Genetic redundancy in soybean photoresponses associated with duplication of the phytochrome A gene. Genetics 180:995-1007. https://doi.org/10.1534/genetics. 108.092742

Lu S, Zhao X, Hu Y, Liu S, Nan H, Li X, Fang C, Cao D, Shi X, Kong L, Su T, Zhang F, Li S, Wang Z, Yuan X, Cober ER, Weller JL, Liu B, Hou X, Tian Z, Kong F (2017) Natural variation at the soybean $\mathrm{J}$ locus improves adaptation to the tropics and enhances yield. Nat Genet 49:773-779. https://doi.org/10.1038/ng.3819

Lu S, Dong L, Fang C, Liu S, Kong L, Cheng Q Chen L, Su T, Nan H, Zhang D, Zhang L, Wang Z, Yang Y, Yu D, Liu X, Yang Q Lin X,
Tang Y, Zhao X, Yang X, Tian C, Xie Q, Li X, Yuan X, Tian Z, Liu B, Weller JL, Kong F (2020) Stepwise selection on homeologous PRR genes controlling flowering and maturity during soybean domestication. Nat Genet 52:428-436. https://doi. org/10.1038/s41588-020-0604-7

Matsuoka Y, Vigouroux Y, Goodman MM, Sanchez GJ, Buckler E, Doebley J (2002) A single domestication for maize shown by multilocus microsatellite genotyping. Proc Natl Acad Sci USA 99:6080-6084. https://doi.org/10.1073/pnas.052125199

Meyer RS, Purugganan MD (2013) Evolution of crop species: genetics of domestication and diversification. Nat Rev Genet 14:840-852. https://doi.org/10.1038/nrg3605

Miranda C, Scaboo A, Cober E, Denwar N, Bilyeu K (2020) The effects and interaction of soybean maturity gene alleles controlling flowering time, maturity, and adaptation in tropical environments. BMC Plant Biol 20:65. https://doi. org/10.1186/s12870-020-2276-y

Molina J, Sikora M, Garud N, Flowers JM, Rubinstein S, Reynolds A, Huang P, Jackson S, Schaal BA, Bustamante CD, Boyko AR, Purugganan MD (2011) Molecular evidence for a single evolutionary origin of domesticated rice. Proc Natl Acad Sci USA 108:8351-8356. https://doi.org/10.1073/pnas. 1104686108

Mulki MA, von Korff M (2016) CONSTANS controls floral repression by up-regulating VERNALIZATION2 (VRN-H2) in Barley. Plant Physiol 170:325-337. https://doi.org/10.1104/pp.15. 01350

Müller NA, Wijnen CL, Srinivasan A, Ryngajllo M, Ofner I, Lin T, Ranjan A, West D, Maloof JN, Sinha NR, Huang S, Zamir D, Jiménez-Gómez JM (2016) Domestication selected for deceleration of the circadian clock in cultivated tomato. Nat Genet 48:89-93. https://doi.org/10.1038/ng.3447

Müller NA, Zhang L, Koornneef M, Jiménez-Gómez JM (2018) Mutations in EID1 and LNK2 caused light-conditional clock deceleration during tomato domestication. Proc Natl Acad Sci USA 115:7135-7140. https://doi.org/10.1073/pnas. 1801862115

Naranjo L, Talón M, Domingo C (2014) Diversity of floral regulatory genes of japonica rice cultivated at northern latitudes. BMC Genomics 15:101. https://doi.org/10.1186/ 1471-2164-15-101

Nemoto Y, Hori K, Izawa T (2018) Fine-tuning of the setting of critical day length by two casein kinases in rice photoperiodic flowering. J Exp Bot 69:553-565. https://doi.org/10.1093/ jxb/erx412

Nishida H, Ishihara D, Ishii M, Kaneko T, Kawahigashi H, Akashi Y, Saisho D, Tanaka K, Handa H, Takeda K, Kato K (2013a) Phytochrome $\mathrm{C}$ is a key factor controlling long-day flowering in Barley. Plant Physiol 163:804-814. https://doi.org/10. 1104/pp.113.222570

Nishida H, Yoshida T, Kawakami K, Fujita M, Long B, Akashi Y, Laurie DA, Kato K (2013b) Structural variation in the $5^{\prime}$ upstream region of photoperiod-insensitive alleles Ppd-A1a and Ppd-B1a identified in hexaploid wheat (Triticum aestivum L.), and their effect on heading time. Mol Breed 31:27-37. https://doi.org/10.1007/s11032-012-9765-0

Ogiso E, Takahashi Y, Sasaki T, Yano M, Izawa T (2010) The role of casein kinase II in flowering time regulation has diversified during evolution. Plant Physiol 152:808-820. https://doi. org/10.1104/pp.109.148908

Ogiso-Tanaka E, Matsubara K, Yamamoto S, Nonoue Y, Wu J, Fujisawa $\mathrm{H}$, Ishikubo $\mathrm{H}$, Tanaka T, Ando T, Matsumoto T, Yano M (2013) Natural variation of the RICE FLOWERING LOCUS T 1 contributes to flowering time divergence in rice. PLoS ONE 8:e75959. https://doi.org/10.1371/journal.pone.0075959 
Pnueli L, Carmel-Goren L, Hareven D, Gutfinger T, Alvarez J, Ganal M, Zamir D, Lifschitz E (1998) The SELF-PRUNING gene of tomato regulates vegetative to reproductive switching of sympodial meristems and is the ortholog of CEN and TFL1. Development 125:1979-1989

Romero Navarro JA, Willcox M, Burgueño J, Romay C, Swarts K, Trachsel S, Preciado E, Terron A, Delgado HV, Vidal V, Ortega A, Banda AE, Montiel NOG, Ortiz-Monasterio I, Vicente FS, Espinoza AG, Atlin G, Wenzl P, Hearne S, Buckler ES (2017) A study of allelic diversity underlying flowering-time adaptation in maize landraces. Nat Genet 49:476-480. https://doi. org/10.1038/ng.3784

Salvi S, Sponza G, Morgante M, Tomes D, Niu X, Fengler KA, Meeley R, Ananiev EV, Svitashev S, Bruggemann E, Li B, Hainey CF, Radovic S, Zaina G, Rafalski J-A, Tingey SV, Miao G-H, Phillips RL, Tuberosa R (2007) Conserved noncoding genomic sequences associated with a flowering-time quantitative trait locus in maize. Proc Natl Acad Sci USA 104:11376-11381. https://doi.org/10.1073/pnas.0704145104

Sedivy EJ, Wu F, Hanzawa Y (2017) Soybean domestication: the origin, genetic architecture and molecular bases. New Phytol 214:539-553. https://doi.org/10.1111/nph.14418

Seki M, Chono M, Matsunaka H, Fujita M, Oda S, Kubo K, KiribuchiOtobe C, Kojima H, Nishida H, Kato K (2011) Distribution of photoperiod-insensitive alleles Ppd-B1a and Ppd-D1a and their effect on heading time in Japanese wheat cultivars. Breed Sci 61:405-412. https://doi.org/10.1270/jsbbs.61.405

Seki M, Chono M, Nishimura T, Sato M, Yoshimura Y, Matsunaka H, Fujita M, Oda S, Kubo K, Kiribuchi-Otobe C, Kojima H, Nishida H, Kato K (2013) Distribution of photoperiod-insensitive allele Ppd-A1a and its effect on heading time in Japanese wheat cultivars. Breed Sci 63:309-316. https://doi.org/10. $1270 /$ jsbbs.63.309

Shalit A, Rozman A, Goldshmidt A, Alvarez JP, Bowman JL, Eshed Y, Lifschitz E (2009) The flowering hormone florigen functions as a general systemic regulator of growth and termination. Proc Natl Acad Sci USA 106:8392-8397. https://doi.org/10. 1073/pnas.0810810106

Shaw LM, Li C, Woods DP, Alvarez MA, Lin H, Lau MY, Chen A, Dubcovsky J (2020) Epistatic interactions between PHOTOPERIOD1, CONSTANS1 and CONSTANS2 modulate the photoperiodic response in wheat. PLoS Genet 16:e1008812. https://doi.org/10.1371/journal.pgen.1008812

Song J, Zhang S, Wang X, Sun S, Liu Z, Wang K, Wan H, Zhou G, Li R, Yu H, Cui X (2020) Variations in both FTL1 and SP5G, two tomato FT paralogs, control day-neutral flowering. Mol Plant 13:939-942. https://doi.org/10.1016/j.molp.2020.05.004

Soyk S, Müller NA, Park SJ, Schmalenbach I, Jiang K, Hayama R, Zhang L, Van Eck J, Jiménez-Gómez JM, Lippman ZB (2017) Variation in the flowering gene SELF PRUNING $5 \mathrm{G}$ promotes day-neutrality and early yield in tomato. Nat Genet 49:162-168. https://doi.org/10.1038/ng.3733

Stacey G (2008) Genetics and genomics of soybean. Springer, New York

Sun H, Wang C, Chen X, Liu H, Huang Y, Li S, Dong Z, Zhao X, Tian F, Jin W (2020) dlf1 promotes floral transition by directly activating ZmMADS4 and ZmMADS67 in the maize shoot apex. New Phytol. https://doi.org/10.1111/nph.16772

Takahashi Y, Shomura A, Sasaki T, Yano M (2001) Hd6, a rice quantitative trait locus involved in photoperiod sensitivity, encodes the subunit of protein kinase CK2. Proc Natl Acad Sci USA 98:7922-7927. https://doi.org/10.1073/pnas. 111136798

Takahashi Y, Teshima KM, Yokoi S, Innan H, Shimamoto K (2009) Variations in Hd1 proteins, Hd3a promoters, and Ehd1 expression levels contribute to diversity of flowering time in cultivated rice. Proc Natl Acad Sci USA 106:4555-4560. https://doi.org/10.1073/pnas.0812092106

Thornsberry JM, Goodman MM, Doebley J, Kresovich S, Nielsen D, Buckler ES (2001) Dwarf8 polymorphisms associate with variation in flowering time. Nat Genet 28:286-289. https:// doi.org/10.1038/90135

Tsuji H, Taoka K, Shimamoto K (2011) Regulation of flowering in rice: two florigen genes, a complex gene network, and natural variation. Curr Opin Plant Biol 14:45-52. https://doi.org/10. 1016/j.pbi.2010.08.016

Turner A, Beales J, Faure S, Dunford RP, Laurie DA (2005) The pseudo-response regulator Ppd-H1 provides adaptation to photoperiod in barley. Science 310:1031-1034. https://doi. org/10.1126/science.1117619

Wang Y, Gu Y, Gao H, Qiu L, Chang R, Chen S, He C (2016) Molecular and geographic evolutionary support for the essential role of GIGANTEAa in soybean domestication of flowering time. BMC Evol Biol 16:79. https://doi.org/10. 1186/s12862-016-0653-9

Wang W, Mauleon R, Hu Z, Chebotarov D, Tai S, Wu Z, Li M, Zheng T, Fuentes RR, Zhang F, Mansueto L, Copetti D, Sanciangco M, Palis KC, Xu J, Sun C, Fu B, Zhang H, Gao Y, Zhao X, Shen F, Cui $\mathrm{X}, \mathrm{Yu} \mathrm{H}$, Li Z, Chen M, Detras J, Zhou Y, Zhang X, Zhao Y, Kudrna D, Wang C, Li R, Jia B, Lu J, He X, Dong Z, Xu J, Li Y, Wang M, Shi J, Li J, Zhang D, Lee S, Hu W, Poliakov A, Dubchak I, Ulat VJ, Borja FN, Mendoza JR, Ali J, Li J, Gao Q Niu Y, Yue Z, MaEB N, Talag J, Wang X, Li J, Fang X, Yin Y, Glaszmann J-C, Zhang J, Li J, Hamilton RS, Wing RA, Ruan J, Zhang G, Wei C, Alexandrov N, McNally KL, Li Z, Leung H (2018) Genomic variation in 3,010 diverse accessions of Asian cultivated rice. Nature 557:43-49. https://doi.org/10.1038/s41586-0180063-9

Wang P, Xiong Y, Gong R, Yang Y, Fan K, Yu S (2019) A key variant in the cis-regulatory element of flowering gene Ghd8 associated with cold tolerance in rice. Sci Rep. https://doi.org/10. 1038/s41598-019-45794-9

Wang L, Sun S, Wu T, Liu L, Sun X, Cai Y, Li J, Jia H, Yuan S, Chen L, Jiang B, Wu C, Hou W, Han T (2020) Natural variation and CRISPR/Cas9-mediated mutation in GmPRR37 affect photoperiodic flowering and contribute to regional adaptation of soybean. Plant Biotechnol J. https://doi.org/10.1111/pbi. 13346

Watanabe S, Hideshima R, Xia Z, Tsubokura Y, Sato S, Nakamoto Y, Yamanaka N, Takahashi $R$, Ishimoto $M$, Anai $T$, Tabata $S$, Harada K (2009) Map-based cloning of the gene associated with the soybean maturity Locus E3. Genetics 182:1251-1262. https://doi.org/10.1534/genetics.108. 098772

Watanabe S, Xia Z, Hideshima R, Tsubokura Y, Sato S, Yamanaka N, Takahashi R, Anai T, Tabata S, Kitamura K, Harada K (2011) A map-based cloning strategy employing a residual heterozygous line reveals that the GIGANTEA gene is involved in soybean maturity and flowering. Genetics 188:395-407. https://doi.org/10.1534/genetics.110.125062

Wei X, Jiang L, Xu J, Zhang W, Lu G, Zhang Y, Wan J (2008) Genetic analyses of heading date of Japonica rice cultivars from Northeast China. Field Crop Res 107:147-154. https://doi. org/10.1016/j.fcr.2008.01.008

Wei X, Xu J, Guo H, Jiang L, Chen S, Yu C, Zhou Z, Hu P, Zhai H, Wan J (2010) DTH8 suppresses flowering in rice, influencing plant height and yield potential simultaneously. Plant Physiol 153:1747-1758. https://doi.org/10.1104/pp.110.156943

Wu W, Zheng X-M, Lu G, Zhong Z, Gao H, Chen L, Wu C, Wang H-J, Wang Q Zhou K, Wang J-L, Wu F, Zhang X, Guo X, Cheng Z, Lei C, Lin Q, Jiang L, Wang H, Ge S, Wan J (2013) Association of functional nucleotide polymorphisms at DTH2 with the 
northward expansion of rice cultivation in Asia. Proc Natl Acad Sci USA 110:2775-2780. https://doi.org/10.1073/pnas. 1213962110

Wu F, Sedivy EJ, Price WB, Haider W, Hanzawa Y (2017) Evolutionary trajectories of duplicated FT homologues and their roles in soybean domestication. Plant J 90:941-953. https://doi.org/10.1111/tpj.13521

Wu M, Liu H, Lin Y, Chen J, Fu Y, Luo J, Zhang Z, Liang K, Chen S, Wang F (2020) In-frame and frame-shift Editing of the Ehd1 gene to develop Japonica rice with prolonged basic vegetative growth periods. Front Plant Sci. https://doi.org/10.3389/ fpls.2020.00307

Würschum T, Boeven PHG, Langer SM, Longin CFH, Leiser WL (2015) Multiply to conquer: copy number variations at PpdB1 and Vrn-A1 facilitate global adaptation in wheat. BMC Genet 16:96. https://doi.org/10.1186/s12863-015-0258-0

Würschum T, Langer SM, Longin CFH, Tucker MR, Leiser WL (2018) A three-component system incorporating Ppd-D1, copy number variation at Ppd-B1, and numerous small-effect quantitative trait loci facilitates adaptation of heading time in winter wheat cultivars of worldwide origin. Plant Cell Environ 41:1407-1416. https://doi.org/10.1111/pce.13167

Xia Z, Watanabe S, Yamada T, Tsubokura Y, Nakashima H, Zhai H, Anai T, Sato S, Yamazaki T, Lü S, Wu H, Tabata S, Harada K (2012) Positional cloning and characterization reveal the molecular basis for soybean maturity locus E1 that regulates photoperiodic flowering. Proc Natl Acad Sci USA 109:E21552164. https://doi.org/10.1073/pnas.1117982109

Xu M, Xu Z, Liu B, Kong F, Tsubokura Y, Watanabe S, Xia Z, Harada K, Kanazawa A, Yamada T, Abe J (2013) Genetic variation in four maturity genes affects photoperiod insensitivity and phyA-regulated post-flowering responses of soybean. BMC Plant Biol 13:91. https://doi.org/10.1186/1471-2229-13-91

Xu M, Yamagishi N, Zhao C, Takeshima R, Kasai M, Watanabe S, Kanazawa A, Yoshikawa N, Liu B, Yamada T, Abe J (2015) The soybean-specific maturity gene E1 family of floral repressors controls night-break responses through down-regulation of FLOWERING LOCUS $\mathrm{T}$ orthologs. Plant Physiol 168:1735-1746. https://doi.org/10.1104/pp.15.00763

Xue W, Xing Y, Weng X, Zhao Y, Tang W, Wang L, Zhou H, Yu S, Xu C, Li X, Zhang Q (2008) Natural variation in Ghd7 is an important regulator of heading date and yield potential in rice. Nat Genet 40:761-767. https://doi.org/10.1038/ng.143

Yan L, Loukoianov A, Tranquilli G, Helguera M, Fahima T, Dubcovsky J (2003) Positional cloning of the wheat vernalization gene VRN1. Proc Natl Acad Sci USA 100:6263-6268. https://doi.org/10.1073/pnas.0937399100

Yan L, Loukoianov A, Blechl A, Tranquilli G, Ramakrishna W, SanMiguel P, Bennetzen JL, Echenique V, Dubcovsky J (2004) The wheat VRN2 gene is a flowering repressor downregulated by vernalization. Science 303:1640-1644. https:// doi.org/10.1126/science.1094305

Yang FP, Zhang XK, Xia XC, Laurie DA, Yang WX, He ZH (2009) Distribution of the photoperiod insensitive Ppd-D1a allele in Chinese wheat cultivars. Euphytica 165:445-452. https://doi. org/10.1007/s10681-008-9745-y
Yang Q, Li Z, Li W, Ku L, Wang C, Ye J, Li K, Yang N, Li Y, Zhong T, Li J, Chen Y, Yan J, Yang X, Xu M (2013) CACTA-like transposable element in ZmCCT attenuated photoperiod sensitivity and accelerated the postdomestication spread of maize. Proc Natl Acad Sci USA 110:16969-16974. https://doi.org/10.1073/ pnas.1310949110

Yano M, Katayose Y, Ashikari M, Yamanouchi U, Monna L, Fuse T, Baba T, Yamamoto K, Umehara Y, Nagamura Y, Sasaki T (2000) Hd1, a major photoperiod sensitivity quantitative trait locus in rice, is closely related to the Arabidopsis flowering time gene CONSTANS. Plant Cell 12:2473-2483. https://doi. org/10.1105/tpc.12.12.2473

Zhang J, Zhou X, Yan W, Zhang Z, Lu L, Han Z, Zhao H, Liu H, Song P, Hu Y, Shen G, He Q, Guo S, Gao G, Wang G, Xing Y (2015) Combinations of the Ghd7, Ghd8 and Hd1 genes largely define the ecogeographical adaptation and yield potential of cultivated rice. New Phytol 208:1056-1066. https://doi.org/ $10.1111 /$ nph.13538

Zhang S, Jiao Z, Liu L, Wang K, Zhong D, Li S, Zhao T, Xu X, Cui X (2018) Enhancer-promoter interaction of SELF PRUNING 5G shapes photoperiod adaptation. Plant Physiol 178:1631-1642. https://doi.org/10.1104/pp.18.01137

Zhang B, Liu H, Qi F, Zhang Z, Li Q, Han Z, Xing Y (2019) Genetic interactions among Ghd7, Ghd8, OsPRR37 and Hd1 contribute to large variation in heading date in rice. Rice (N Y) 12:48. https://doi.org/10.1186/s12284-019-0314-x

Zhao J, Chen H, Ren D, Tang H, Qiu R, Feng J, Long Y, Niu B, Chen D, Zhong T, Liu Y-G, Guo J (2015) Genetic interactions between diverged alleles of Early heading date 1 (Ehd1) and Heading date 3a (Hd3a)/ RICE FLOWERING LOCUS T1 (RFT1) control differential heading and contribute to regional adaptation in rice (Oryza sativa). New Phytol 208:936-948. https://doi. org/10.1111/nph.13503

Zhao C, Takeshima R, Zhu J, Xu M, Sato M, Watanabe S, Kanazawa A, Liu B, Kong F, Yamada T, Abe J (2016) A recessive allele for delayed flowering at the soybean maturity locus E9 is a leaky allele of FT2a, a FLOWERING LOCUS T ortholog. BMC Plant Biol 16:20. https://doi.org/10.1186/s12870-016-0704-9

Zhao L, Li M, Xu C, Yang X, Li D, Zhao X, Wang K, Li Y, Zhang X, Liu L, Ding F, Du H, Wang C, Sun J, Li W (2018) Natural variation in GmGBP1 promoter affects photoperiod control of flowering time and maturity in soybean. Plant J 96:147-162. https://doi.org/10.1111/tpj.14025

Zhu J, Takeshima R, Harigai K, Xu M, Kong F, Liu B, Kanazawa A, Yamada T, Abe J (2019) Loss of function of the E1-like-b gene associates with early flowering under long-day conditions in soybean. Front Plant Sci. https://doi.org/10.3389/fpls.2018. 01867

Zong W, Ren D, Huang M, Sun K, Feng J, Zhao J, Xiao D, Xie W, Liu S, Zhang H, Qiu R, Tang W, Yang R, Chen H, Xie X, Chen L, Liu Y, Guo J (2020) Strong photoperiod sensitivity is controlled by cooperation and competition among Hd1, Ghd7 and DTH8 in rice heading. New Phytol. https://doi.org/10.1111/nph. 16946 